\title{
THE INFLUENCE OF SCHOOL FACTORS ON STUDENTS' SELF-CONCEPT: FINDINGS FROM PIRLS 2016
}

\author{
Andrejs Geske, Kristine Kampmane, Antra Ozola \\ University of Latvia
}

\begin{abstract}
In recent years, studies have put emphasis on school not only as an institution for academic achievement but also as an environment for social-emotional development, learning and shaping students' attitudes and beliefs. There are studies that show the correlation between the environment and development of a child's self-concept, as well as the correlation between self-concept and school anxiety. The studies have discovered very strong relationship between school success factors such as enjoyment, engagement and achievement and the school's climate. However, there are many unknown answers to the question how significant the role of school is in shaping child's awareness of self, selfconfidence, self-concept, self-efficacy and self-esteem. The purpose of this study is, first, to analyse different studies on the impact of school on students' self-concept, academic selfconcept and self-efficacy and, second, to identify school factors that influence students' selfconcept from the PIRLS 2016 study. The research question is as follows: which school level factors influence students' academic self-concept?

Authors of this article used linear regression, correlation and frequency analysis of the International Association's for the Evaluation of Educational Achievement (IEA) Progress in International Reading Literacy Study (PIRLS) 2016 data from 8 countries around the Baltic Sea.

The results showed that the $4^{\text {th }}$ graders' academic self-concept in reading correlated with reading achievement and engagement in reading lessons, self-concept had a negative correlation with bullying, absenteeism from school and tiredness during school day. Overall, the authors of this article found that in the PIRLS 2016 study the direct impact of school factors on students' academic self-concept in reading is very low.
\end{abstract}

Keywords: academic self-concept, PIRLS, self-concept, self-confidence, self-efficacy, self-esteem.

\section{Introduction}

Every child is surrounded by a community or a social system (Bronfenbrenner, 1979; Penn, 2005). The first and closest community or micro-system through childhood for a child usually is one's family. The 
family's impact on child's well-being, self-system development and achievement has been well studied; there are studies that support the view of significance of various factors like quality time spent together (Harwood et al., 2008; Geske \& Ozola, 2020; Mullis et al., 2017), social-economic status (Filippin \& Paccagnella, 2011; Mullis et al., 2017; Geske et al., 2021) and reading enjoyment of parents (Mullis et al., 2017; Geske et al., 2021). An educational institution is another community or meso-system a child is very closely related to. Every child becomes a member of this community with the background given in one's family. As world's economies need employees that have developed competencies, behaviours, attitudes and personal qualities rather than those who just know the facts (Fadel et al., 2015), a common contemporary understanding is that the role of school is not only to educate students according to the curriculum but to upbring them (Trinite, 2020) and enhance the development of their "soft skills" including social-emotional skills (Scheerens et al., 2020). One dimension of soft-skills is related to positive beliefs about self, self-confidence, self-efficacy, self-awareness, self-esteem; according to Lippman and colleagues (2015), the term "self-concept" integrates it all in one concept. Shavelson and colleagues (1976) state that every human has self-concept beliefs about oneself that are general and domain specific. Reading is the skill that shapes person's domain specific beliefs about self. As it is known, reading is more than just ability to sequence written symbols; it is an ability to understand the written form of language, it provides the ability to select the information that is needed in the process of learning, decision making and critical thinking (Schleicher, 2019). Reading literacy is indicated as one of the top skills for future education and economies (Fadel et al., 2015; Scheerens et al., 2020); moreover, Moterri and Frandell (2013) emphasize that reading is one of the basic needs for humans in the $21^{\text {st }}$ century. Tubele and Serova (2020) state that reading literacy skills can serve as an indicator for one's quality of life. It is proved by several studies cited in McArthur and colleagues (2020) that there is a significant association between poor reading literacy skills and poor self-concept and anxiety.

IEA (International Association for the Evaluation of Educational Achievement) every five years conducts the PIRLS (Progress in International Reading Literacy Study) which gathers data about $4^{\text {th }}$ grade students' reading achievement, students' reading literacy competences and background data about student, school, family and personal factors that possibly could affect the achievement in reading literacy from 61 countries. As the age of 10 is approximately the age in which student's presumption about what one can and cannot comes close to one's real abilities (Bjorklund, 2000), in Grade 4 students have reached the appropriate age for studying their beliefs about themselves. 
The questions that are worth examining are the following: first, can the school impact child's beliefs about self; second, are these general or domain specific beliefs about self; third, if the school can impact or shape these beliefs, then what are the factors and their significance?

The purpose of this study is to analyse different studies about the impact of school on students' self-concept, academic self-concept and self-efficacy and to identify factors that are related to school and influence students' academic self-concept in reading in the PIRLS 2016.

\section{Theoretical background}

It has been found that person's belief system about self has an impact on one's behaviour, attitudes, deeds, actions, chosen tasks and goals, task performance, productivity and persistence (Bandura, 2001; Pervin \& Cervone, 2013; Tabernero \& Wood, 2009). Besides, beliefs might be and might not be related to reality (Pervin \& Cervone, 2013), they might even be taken over from one's family (Filippin \& Paccagnella, 2011), but they all form a person and determine one's behaviour accordingly.

The term self-concept has a variety of definitions. There are authors who define self-concept as a dynamic pattern of perceptions that makes the structure of personality (Pervin \& Cervone, 2013) or a descriptive component or knowledge structure of the self (Larsen \& Buss 2018). Berk (2009) gives the most extensive definition stating that the concept of self is everything, i. e., abilities, attitudes and attributes, beliefs that define oneself. Hooper and colleagues (2015) define self-concept as student's own perceived competence. Marsh and colleagues (1988), Pervin and Cervone (2013), Larsen and Buss (2018) acknowledge that self-concept is developing, dynamic, complex, structured and multi layered; and in this case it can be divided into general self-concept, academic self-concept (in particular academic domain) and non-academic self-concept (social, emotional, etc.), with reference to Areepattamannil and Freeman (2008). Academic self-concept is defined as one's belief of academic abilities (Harwood et al., 2008). Ishak (2014) adds that the academic self-concept serves as a mediator for non-academic self-concept and enhances learning. It is common that terms academic self-concept, domain-specific self-esteem, self-confidence in a particular subject and perceived self-efficacy are used as synonyms because they belong to the person's self-belief system. Whitcomb and Merrell (2013) explain that the above-mentioned terms form one of the basic human capabilities, according to social cognitive theory, the self-reflective capability. Bong and Skaalvik (2003) stress the difference between academic self-confidence and perceived self-efficacy, emphasising that, as an academic self-concept, beliefs are based on previous experience in the 
academic subject whereas self-efficacy is formed from future beliefs on specific task performance in the subject. Both are closely related to motivational, emotional and performance outcomes, but, in addition, self-efficacy predicts self-regulatory processes and forms an important part of academic self-concept.

Academic self-concept as well as perceived self-efficacy is strongly related to academic achievement (Marsh et al., 1988; Harwood et al., 2008, Pervin \& Cervone, 2013, Vesić et al., 2021). Academic self-concept predicts academic achievement better than intrinsic motivation and enjoyment (Vesić et al., 2021). Academic self-concept is a significant mediating variable for desirable outcomes (Shavelson et al., 1976; Marsh \& Craven, 2005). Academic self-concept is significantly related to academic buoyancy in mathematics and reading domains (Colmar et al., 2019). Some studies show that academic self-concept is reciprocal in nature with academic achievement (March \& Craven, 2005, McInerney et al., 2012; Chena et al., 2013; Seaton et al., 2013). Sánchez and Roda (2003) suggest that elementary school teachers should foster students' self-concept in order to raise their academic achievement and foster positive peer relationships.

It is well studied that engagement and absenteeism affect learning outcomes and achievement in particular (Hooper et al., 2015). Vesić et al. (2021) highlight that the academic self-concept is lower for students who are absent more often; these students like school less and usually are less emotionally and cognitively engaged and show lower achievement than their peers (Hirschfield \& Gasper, 2011; Vaughn et al., 2013). Students' self-system has a significant effect on school engagement (Fall \& Roberts, 2012; Green et al., 2012). Student's self-concept may serve as a predictor for engagement (Bakadorova et al., 2020) in a way that students with high self-concept are engaged in lessons with variety of forms (Schnitzler et al., 2020). Thus, concluding from the current studies, self-concept is a mediator not only for achievement, but for engagement as well.

Self-concept is closely related to mindset (Dweck, 2006), both are negatively affected by fear, especially by fear of bullying, cyberbullying and school anxiety (Lange et al., 2017; Escortell et al., 2020). Bullying has a negative effect not only on achievement (Hooper et al., 2015), but on global self-concept, and students with low social self-concept are bullied more than students with higher social self-concept (Parada et al., 2005), but as the authors mention, usually low social self-concept is the reason for being bullied (Parada et al., 2005; Houbre et al., 2010). Being a victim lowers the global and social self-concept (Roeleveld, 2011), academic self-concept in math and reading (Caputo, 2014). Meanwhile, demonstrating disruptive behaviours could be a subordinating strategy for low 
self-concept (Marsh et al., 2001). Bullying can have lifelong effects on persons' social relationships and self-views and, if accompanied with troublemaker characteristics, fosters early school drop-offs.

\section{Method}

For the purpose of this study, the authors analysed answers from the PIRLS 2016 students' questionnaire and used students' reading achievement as an additional reference factor. The Baltic Sea region countries were chosen as countries of comparison: Finland, the Russian Federation, Estonia, Latvia, Lithuania, Poland, Germany, Denmark and Sweden, as these countries are comparatively closely located, people have quite similar mentality and some of these countries have had a similar historical development, too.

For the data analysis the authors of this article used linear regression models, correlation and frequency analysis. The purpose of this study was to find factors that influenced students' academic self-concept in reading.

In order to measure students' beliefs about self in reading or academic self-concept in reading, the students' questionnaire in the PIRLS 2016 contains a question "How well do you read? Tell how much you agree with each of these statements." followed by six statements. From this question, a scale titled "Students Confident in Reading Scale" was created. Students' answers were measured in the Likert-type scale with four values from "agree a lot" to "disagree a lot". Each answer was coded into values from 1 to 4 . First two statements were coded directly - 1 for "agree a lot" to 4 - "disagree a lot" but other four were inverse-coded - 1 for "disagree a lot" to 4 - "agree a lot". The six statements were as follow (Hooper et al., 2015):

1. I usually do well in reading;

2. Reading is easy for me;

3. I have trouble reading stories with difficult words;

4. Reading is harder for me than for many of my classmates;

5. Reading is harder for me than any other subject;

6. I am just not good at reading.

This scale was a continuous scale and average values within the scale for each student varied from 2.9 to 13.5, and the Cronbach's Alpha Reliability Coefficient for the selected countries of comparison varied between 0.79 and 0.83 .

In the linear regression analysis, the scale titled "Students Confident in Reading Scale" was used as a dependent variable. Further in this article the authors reference this variable/factor as "Academic Self-Concept in Reading". 
In order to explain the variance of the "Students Confident in Reading Scale" values in the PIRLS 2016, two scales were used for the linear regression analysis as independent variables: "Students Engaged in Reading Lessons Scale" and "Student Bullying Scale" and the answers to two questions: "About how often are you absent from school?" and "How often do you feel tired when you arrive at school?" as these factors were mentioned in the literature as influential factors for self-concept.

The answers on the question "About how often are you absent from school?" were coded with the following values: 1 - once a week, 2 - once every two weeks, 3 - once a month, 4 - never or almost never. Further in this article the authors reference this factor as "Absent from School".

The answers to the question "How often do you feel tired when you arrive at school?" were measured in the Likert-type scale with values from 1 to 4: 1 - every day, 2 - almost every day, 3 - sometimes, 4 - never. Further in this article the authors reference this factor as "Feels Tired".

The scale titled "Students Engaged in Reading Lessons Scale" was created focusing on a question in the PIRLS 2016 students' questionnaire "Think about the reading you do for school. How much do you agree with these statements about your reading lessons?" followed by nine statements. Each statement was measured in the Likert-type scale with four values from "agree a lot" (coded as 1) to "disagree a lot" (coded as 4). The nine statements were the following (Hooper et al., 2015):

1. I like what I read about in school;

2. My teacher gives me interesting things to read;

3. I know what my teacher expects me to do;

4. My teacher is easy to understand;

5. I am interested in what my teacher says;

6. My teacher encourages me to say what I think about what I have read;

7. My teacher lets me show what I have learned;

8. My teacher does a variety of things to help us learn;

9. My teacher tells me how to do better when I make a mistake.

This scale was a continuous scale and average values within the scale for each student varied from 2.5 to 13.1 , and the Cronbach's Alpha Reliability Coefficient for the selected countries of comparison varied between 0.81 and 0.86. Further in this article the authors reference this variable/factor as "Engaged in Reading Lessons."

The scale titled "Student Bullying Scale" was created focusing on one question in the PIRLS 2016 students' questionnaire: “During this year, how often have other students from your school done any of the following things to you (including through texting or the Internet)?" followed by eight statements. Each statement was measured in the Likert-type scale. The values 
were coded as follows: 1 - "Never" 2 - "A few times a year" 3 - "Once or twice a month" 4 - "At least once a week." The eight statements were the following (Hooper et al., 2015):

1. Made fun of me or called me names;

2. Left me out of their games or activities;

3. Spread lies about me;

4. Stole something from me;

5. Hit or hurt me (e. g., shoving, hitting, kicking);

6. Made me do things I didn't want to do;

7. Shared embarrassing information about me;

8. Threatened me.

This scale was a continuous scale and average values within the scale for each student varied from 3.3 to 12.9, and the Cronbach's Alpha Reliability Coefficient for the selected countries of comparison varied between 0.79 and 0.85 . Further in this article the authors reference this variable/factor as "Student Bullying".

As the Cronbach's Alpha Reliability Coefficient for all scales is above 0.7, the scales are well-designed, and their internal consistency is excellent.

\section{Results}

Before the linear regression modelling, the authors analysed if there was a correlation between the academic self-concept in reading and other chosen factors, and students' reading achievement (see Table 1). All coefficients given in Table 1 are statistically significant.

Table 1. Correlations of "Academic Self-Concept in Reading" with Four Other Factors and Reading Achievement

\begin{tabular}{|c|c|c|c|c|c|c|c|c|}
\hline $\begin{array}{l}\text { Name of the } \\
\text { Factor }\end{array}$ & 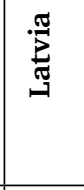 & 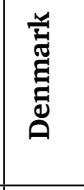 & 点 & 壱 & 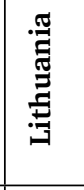 & 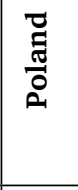 & 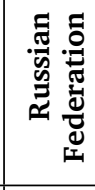 & 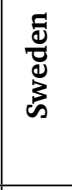 \\
\hline $\begin{array}{l}\text { Absent from } \\
\text { school }\end{array}$ & 0.09 & 0.08 & 0.13 & 0.14 & 0.13 & 0.13 & 0.13 & 0.13 \\
\hline Feels tired & 0.13 & 0.14 & 0.14 & 0.14 & 0.14 & 0.14 & 0.12 & 0.15 \\
\hline $\begin{array}{l}\text { Engaged } \\
\text { in reading } \\
\text { lessons }\end{array}$ & 0.18 & 0.24 & 0.18 & 0.19 & 0.19 & 0.19 & 0.19 & 0.19 \\
\hline $\begin{array}{l}\text { Student } \\
\text { bullying }\end{array}$ & 0.16 & 0.09 & 0.13 & 0.16 & 0.23 & 0.18 & 0.14 & 0.11 \\
\hline $\begin{array}{l}\text { Reading } \\
\text { achievement }\end{array}$ & 0.42 & 0.50 & 0.42 & 0.40 & 0.46 & 0.40 & 0.41 & 0.41 \\
\hline
\end{tabular}


From the chosen factors, the reading achievement has the strongest correlation with students' academic self-concept for all countries of comparison. Students with high achievement in reading have high academic self-concept in reading and vice versa. Students' engagement in reading lessons is the second most correlated factor with academic self-concept in reading for all countries of comparison, except Lithuania. Students who are engaged in reading lessons are more confident in reading than others and vice versa. Although from the countries of comparison Lithuania has the same intensity of bullying in schools as it is in Germany (and that is less than in Latvia and the Russian Federation), bullying is the second most correlated factor with Lithuanian students' academic self-concept in reading. The third most correlated factor for other countries of comparison is students' bullying. Students' bullying scale is inverse-coded, this is the reason why the correlation is positive in numbers but in reality the correlation is negative, i. e. the more students are bullied, the lower academic self-concept they have and vice versa. The factors "Feels Tired" and "Absent from School" have very similar correlation rates with the academic self-concept in reading, except Latvia and Denmark, as they have the lowest correlation values for absenteeism from school. Factors "Feels Tired" and "Absent from School" are inverse-coded, i. e. if students are more tired or more absent from school, they have lower value of the academic self-concept in reading.

As all the correlations from the observed factors were statistically significant, the authors performed multifactor linear regression analysis in order to discover the impact of factors on how the dependent variable is influenced by independent variables and how much of the variance of the dependent variable can be explained with these factors.

First, linear regression models were applied to the independent variable without controlling for the reading achievement, i. e., only "Absent from School" "Feels Tired" "Engaged in Reading Lessons" "Students Bullying" were included in the model. The result of this linear regression analysis is presented in Table 2.

As it can be seen in Table 2, the coefficient of determination $\left(\mathrm{R}^{2}\right)$ for academic self-concept in reading with independent variables of the linear regression model is very low. The highest value for $\mathrm{R}^{2}$ is for Lithuania, i. e., the model explains $9 \%$ of the variance of students' academic self-concept in reading. For Latvia, Finland, the Russian Federation and Sweden, the model only explains $6 \%$ of the variance, in Denmark and Germany - 7\% and in Poland $-8 \%$ of the variance of students' academic self-concept in reading. 
Table 2. Linear Regression Coefficients of Regression Equations Representing How Students' Academic Self-Concept in Reading is Affected by the Set of Selected Factors and the Coefficients of Determination (R2) of These Models

\begin{tabular}{|c|c|c|c|c|c|c|c|c|}
\hline $\begin{array}{l}\text { Name of the } \\
\text { Factor and } R^{2}\end{array}$ & 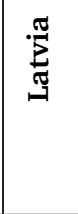 & 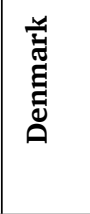 & 胥 & 怘 & 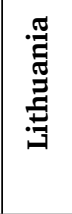 & $\begin{array}{l}\overrightarrow{\tilde{E}} \\
\frac{\pi}{0} \\
\text { : }\end{array}$ & 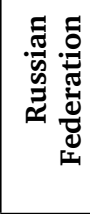 & 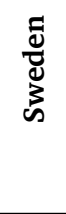 \\
\hline Absent from school & 0.06 & 0.06 & 0.11 & 0.11 & 0.11 & 0.11 & 0.11 & 0.11 \\
\hline Feels tired & 0.07 & 0.08 & 0.08 & 0.09 & 0.08 & 0.08 & 0.05 & 0.09 \\
\hline $\begin{array}{l}\text { Engaged in reading } \\
\text { lessons }\end{array}$ & 0.14 & 0.21 & 0.15 & 0.15 & 0.13 & 0.15 & 0.15 & 0.15 \\
\hline Student bullying & 0.12 & $0.03 *$ & 0.07 & 0.12 & 0.18 & 0.13 & 0.08 & 0.05 \\
\hline $\mathrm{R}^{2}$ & 0.06 & 0.07 & 0.06 & 0.07 & 0.09 & 0.08 & 0.06 & 0.06 \\
\hline
\end{tabular}

* not significant, $p>0.05$

Overall, the strongest impact on academic self-concept is from the factor "Engaged in Reading Lessons" except for Lithuania, with the highest value of 0.21 for Denmark and the lowest, i. e. 0.13 for Lithuania. The second strongest impact on academic self-concept is from the variable "Absent from School". School absenteeism is almost twice as important for such countries as Finland, Germany, Lithuania, Poland, the Russian Federation and Sweden than it is in Latvia and Denmark. The factor of student bullying is the strongest for Lithuania with the highest value 0.18 from all the variables. On the contrary, Denmark is the only country in this model where bullying is not a significant factor, and in Sweden bullying is more than three times less important for academic self-concept in reading than in Lithuania. In Latvia, Germany, Poland and the Russian Federation bullying is the second strongest factor from the chosen set which influences students' academic self-concept in reading. Although German fourth graders are the most tired at school, i. e., $49 \%$ of students stated that they were tired at school every day or almost every day, the impact on academic self-concept in reading is as high as in Sweden, where $37 \%$ of students indicated being tired every day or almost every day. The students of the Russian Federation are the least tired from countries of comparison, i. e. $29 \%$ of students reported being tired at school every day or almost every day; thus, the impact of tiredness on academic self-concept in reading is the lowest. Denmark, Finland, Lithuania and Poland have an equal value and just 0.1 points less than Germany and Sweden. 
In order to increase the explained variance of academic self-concept in reading the authors of this article added students' reading achievement in the linear regression model as an additional factor. The result of this linear regression analysis is shown in Table 3.

Table 3. Linear Regression Coefficients of Regression Equations Representing How Students' Academic Self-Concept in Reading is Affected by the Selected Factor and Coefficients of Determination $\left(R^{2}\right)$ of These Models

\begin{tabular}{|c|c|c|c|c|c|c|c|c|}
\hline $\begin{array}{l}\text { Country } \\
\text { Name of the } \\
\text { Factor and } R^{2} \\
\end{array}$ & 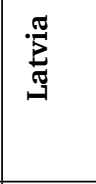 & 气ั: & 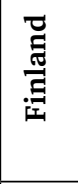 & 怘 & 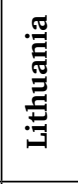 & 范 & 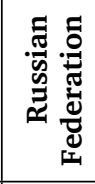 & 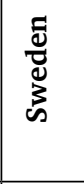 \\
\hline $\begin{array}{l}\text { Absent from } \\
\text { school }\end{array}$ & $0.02 *$ & $0.02 *$ & 0.04 & 0.05 & 0.04 & $0.03 *$ & 0.05 & 0.06 \\
\hline Feels tired & 0.04 & 0.06 & 0.03 & 0.07 & 0.04 & $0.03 *$ & 0.04 & 0.06 \\
\hline $\begin{array}{l}\text { Engaged in } \\
\text { reading lessons }\end{array}$ & 0.15 & 0.15 & 0.13 & 0.12 & 0.12 & 0.18 & 0.16 & 0.16 \\
\hline Student bullying & 0.05 & $0.02 *$ & 0.04 & 0.07 & 0.11 & 0.07 & 0.05 & $0.02 *$ \\
\hline $\begin{array}{l}\text { Reading } \\
\text { achievement }\end{array}$ & 0.39 & 0.47 & 0.39 & 0.36 & 0.42 & 0.39 & 0.4 & 0.39 \\
\hline $\mathrm{R}^{2}$ & 0.21 & 0.28 & 0.2 & 0.19 & 0.26 & 0.21 & 0.21 & 0.21 \\
\hline
\end{tabular}

* not significant, $p>0.05$

By adding reading achievement as an additional factor, it was possible to increase the amount of explained variance by $15 \%$ on average. The highest increase in explained variance is for Denmark $-R^{2}$ increased by 0.21 , followed by Lithuania with increase by 0.17 , Latvia, the Russian Federation, Sweden - by 0.15 , Poland - by 0.13 and Germany - by 0.12 .

As it was already presented in Table 1 , the reading achievement had the strongest correlation with academic self-concept in reading. This impact is seen in the linear regression models, too. When controlling for the reading achievement, several regression coefficients of all the factors decreased and lessened their impact and few factors in different countries became insignificant at all. The change in the values of regression coefficients can be explained by the fact that all of these factors are very closely related to reading achievement, and reading achievement being the most significant factor for academic self-concept in reading. With reading achievement having the strongest influence, the engagement in reading lessons is the second most important factor for all the countries of comparison, including Lithuania with all coefficients being significant. When controlling for 
reading achievement, the students' engagement in reading lessons decreased its impact in Denmark - by 0.6, Finland - by 0.2 , Germany - by 0.3 , Lithuania - by 0.1 , but increased its value in Latvia - by 0.1 , Poland - by 0.3, the Russian Federation - by 0.1 and Sweden - by 0.1 . The factor of students being bullied decreased its importance in all the counties of comparison and was not significant in Denmark as well as in Sweden. It means that the students' academic self-concept in reading is less affected by bullying if a student has higher achievement in reading. Nevertheless, the strongest impact of bullying is seen in Lithuanian data. When reading achievement is controlled, bullying, absenteeism from school and tiredness have lessened their effect on the academic self-concept in reading. Absenteeism from school is not a significant factor for students in Denmark, Latvia and Poland, and tiredness is not important for Poland. Students being absent from school impacts their academic self-concept in reading the most in Sweden, followed by Germany, the Russian Federation, Finland and Lithuania, but tiredness impacts academic self-concept in reading the most in Germany, followed by Denmark, Sweden, Latvia, Lithuania, the Russian Federation and Finland.

\section{Discussion and Conclusions}

Looking internationally, the factor prevalence in population does not explain the value of correlation between the chosen factor and the academic self-concept in reading, i. e., Latvia has the highest percentage of the bullying in schools, but in Lithuania bullying in schools is more correlated with academic self-concept in reading. Students in Finland and Poland are absent from school most often; however, the correlation with the academic self-concept in reading has the same value as in Lithuania and the Russian Federation, although students from these countries attend school most regularly. The same is true for the linear regression equations.

Some studies claim that the self-concept is related to the "Big-FishLittle-Pond" effect (Marsh, 2005), but others could not prove the existence of this phenomenon (Adegoke, 2015). Analysing the data from the PIRLS 2016, the authors of this article found that, examining internationally, Latvian students have the lowest academic self-concept among countries of comparison despite being at the $4^{\text {th }}$ place by reading achievement among the chosen countries.

Tosto et al. (2016), Dotter and Lowe (2011) cite several studies where the importance of classroom on students' self-confidence is emphasized, but the authors of this research could not find any significant impact of class level factors on students' academic self-confidence.

This research supports other studies mentioned in the theoretical background where significant relationship between students' academic 
self-concept and achievement was found. When controlling for reading achievement in the linear regression analysis, all other factors reduced the impact in the model and achievement became the strongest factor, it means that academic self-concept in reading is best explained by reading achievement.

Despite the studies cited in the theoretical background that prove the impact of bullying and victimisation on students' self-concept and beliefs about self, in this research the impact of bullying on academic self-concept in reading was relatively low. The authors assume that there might be two reasons: first, the PIRLS 2016 questionnaire might not cover all forms of bullying; second, it has been discovered that social self-concept is affected negatively by bullying more than general self-concept, however, the authors explored the academic self-concept in reading in the PIRLS 2016.

As it is seen in both tables of linear regression models (see Table 2 and Table 3) the overall impact of school factors other than reading achievement on academic self-concept in reading is relatively low. From all the factors on average the most significant was students' engagement in reading lessons for all countries of comparison, followed by students being bullied and students being absent from school. Although tiredness was significant for all the countries of comparison, when the reading achievement was not controlled, its impact was very low.

As academic self-concept is closely related to soft-skills and social-emotional learning, and for many years, these aspects of learning have not been included into school curriculum it is not surprising that overall impact of school factors on students' academic self-concept is very low. As social-emotional learning is now a part of the curriculum in Latvia, the authors are eager to repeat this analysis with the latest data from PIRLS 2021.

\section{References}

Adegoke, B. A. (2015) The Big-Fish-Little-Pond Effect on Mathematics Self Concept of Junior School Students in Academically Selective and Non-Selective Schools. Journal of Studies in Education, 5(2), 91-105.

Areepattamannil, S., \& Freeman, J. G. (2008). Academic Achievement, Academic SelfConcept, and Academic Motivation of Immigrant Adolescents in the Greater Toronto Area Secondary Schools. Journal of Advanced Academics, 19(4), 700-743.

Bakadorova, O., Lazarides, R., \& Raufelder, D. (2020). Effects of Social and Individual School Self-concepts on School Engagement During Adolescence. European Journal of Psychology of Education, 35(1), 73-91.

Bandura, A. (2001). Social Cognitive Theory: An Agentic Perspective. Annual Review of Psychology, 52(1), 1-26.

Berk, L. A. (2009). Child Development ( $8^{\text {th }}$ ed.). Pearson. 
Bjorklund, D. F. (2000). Children's Thinking Developmental Function and Individual Differences ( $3^{\text {rd }}$ ed.). Whadsworth.

Bong, M., \& Skaalvik, E. M. (2003). Academic Self-Concept and Self-Efficacy: How Different Are They Really? Educational Psychology Review, 15, 1-40.

Bronfenbrenner, U. (1979). The Ecology of Human Development Experiments by Nature and Design. Harvard University Press.

Caputo, A. (2014). Psychological Correlates of School Bullying Victimization: Academic Self-Concept, Learning Motivation and Test Anxiety. International Journal of Educational Psychology, 3(1), 69-99.

Chena, S. K., Yeha, Y. C., Hwang, F. M., \& Lina, S. S. J. (2013). The Relationship Between Academic Self-Concept and Achievement: A Multicohort-Multioccasion Study. Learning and Individual Differences, 23, 172-178.

Colmar, S., Liem, G. A. D., Connor, J., \& Martin, A. J. (2019). Exploring the Relationships Between Academic Buoyancy, Academic Self-concept, and Academic Performance: A Study of Mathematics and Reading among Primary School Students. Educational Psychology, 39(8), 1068-1089.

Dotter, A. M., \& Lowe, K. (2011) Classroom Context, School Engagement, and Academic Achievement in Early Adolescence. $J$ Youth Adolescence, 40(12), 1649-1660.

Dweck, C. S. (2006). Mindset. Random House.

Escortell, R., Delgado, B., \& Martínez-Monteagudo, M. C. (2020). Cybervictimization, Self-Concept, Aggressiveness, and School Anxiety in School Children: A Structural Equations Analysis. Int J Environ Res Public Health, 17(19), 7000-7015.

Fadel, C., Bialik, M., \& Trilling, B. (2015). Four-Dimensional Education. The Center for Curriculum Redesign.

Fall, A. M., \& Roberts, G. (2012). High School Dropouts: Interactions between Social Context, Self-perceptions, School Engagement, and Student Dropout. Journal of Adolescence, 35(4), 787-798.

Filippin, A., \& Paccagnella, M. (2011). Family Background, Self-Confidence and Economic Outcomes, Economics of Education Review, 31(5), 824-834.

Geske, A., \& Ozola, A. (2020). Parents' Impact on Students' Reading Achievement. Proceedings of the International Scientific Conference. Volume III, Society. Integration. Education, 3, 365-666.

Geske, A., Kampmane, K., \& Ozola, A. (2021). The Impact of Family and Individual Factors on $4^{\text {th }}$ Grade Students' Self-Confidence in Reading Literacy: Results from PIRLS 2016, Society Integration Education Proceedings of the International Scientific Conference, 2, 203-213.

Green, J., Liem, G. A. D., Martin, A. J., Colmar, S., Marsh, H. W., \& McInerney, D. (2012). Academic Motivation, Self-concept, Engagement, and Performance in High School: Key Processes from a Longitudinal Perspective. Journal of Adolescence, 35(5), 1111-1122.

Harwood, R., Miller, S. A., \& Vasta, R. (2008). Child Psychology: Development in a Changing Socienty ( $5^{\text {th }}$ ed.). Willey.

Hirschfield, P.J., \& Gasper, J., (2011). The Relationship Between School Engagement and Delinquency in Late Childhood and Early Adolescence. J Youth Adolescence, 40(1), $3-22$. 
Hooper, M., Mullis, V. S. I., \& Martin, O. M. (2015). PIRLS 2016 Context Questionnaire Framework. In Mullis V.S.I. \& Martin O. M. (eds.), PIRLS2016 Assessment Framework, ( $2^{\text {nd }}$ ed., pp. 33-56). Timss \& Pirls International Study Center.

Houbre, B., Tarquinio, C., \& Lanfranchi, J. B. (2010). Expression of Self-Concept and Adjustment Against Repeated Aggressions: The Case of a Longitudinal Study on School Bullying. European Journal of Psychology of Education, 25(1), 105-123.

Ishak, Z. (2014). Non-Academic Self Concept and Academic Achievement: The Indirect Effect Mediated by Academic Self Concept. Research Journal in Organizational Psychology \& Educational Studies, 3(3), 184-188.

Lange, R., Martínez-Garrido, C., \& Ventura, A. (2017). I'm Scared to Go to School! Capturing the Effects of Chronic Daily Fears on Students' Concept of Self. Journal of Applied Measurement, 18(4), 420-433.

Larsen, R., \& Buss, D. M. (2018). Personality Psychology Domains of Knowledge about Human Nature (6 ${ }^{\text {th }}$ ed.). McGrow Hill.

Lippman, L. H., Ryberg, R., Carney, R., \& Moore, K. A. (2015). Workforce Connections. Key "Soft Skills" that Foster Youth Workforce Success: Toward A Consensus Across Fields. Child Trends Publication, 2015(24), 1-56.

Marsh, W. H., Parada, R. H., Yeung, A. S., \& Healey, J. (2001). Aggressive School Troublemakers and Victims: A Longitudinal Model Examining the Pivotal Role of SelfConcept. Journal of Educational Psychology, 93(2), 411-419.

Marsh, W. H., \& Craven, R. G. (2005). Reciprocal Effects of Self-Concept and Achievement: Competing Multidimensional and Unidimensional Perspectives. Australian Association for Research in Education 2005 Conference Papers.

Marsh, W. H. (2005). Big Fish Little Pond Effect on Academic Self-Concept: CrossCultural and Cross-Disciplinary Generalizability. Australian Association for Research in Education 2005 Conference Papers.

Marsh, W. H., Byrne, B. M., \& Shavelson, R. J. (1988). A Multifaceted Academic SelfConcept: Its Hierarchical Structure and Its Relation to Academic Achievement. Journal of Educational Psychology, 80(3), 366-380.

McArthur, G. M., Filardi, N., Francis, D. A., Boyes, M. E., \& Badcock, N. A. (2020). Self-concept in Poor Readers: A Systematic Review and Meta-Analysis. PeerJ Life \& Environment, 8, e8772.

McInerney, D. M., Cheng, R. V., Ching Mok, M. M., \& Lam, A. K. H. (2012). Academic Self-Concept and Learning Strategies: Direction of Effect on Student Academic Achievement. Journal of Advanced Academics, 23(3), 249-269.

Moterri, G. A. S., \& Frandell, T. (2013). Literacy from a Right to Education Perspective. Report of the Director-General of the UNESCO to the UN General Assembly $68^{\text {th }}$ session. UNESCO.

Mullis, I. V. S., Martin, M. O., Foy, P., \& Hooper, M. (2017). PIRLS 2016 International Results in Reading. TIMSS \& PIRLS International Study Center.

Parada, R. H., Marsh, H. W., Craven, R. G., \& Papworth, B. A. (2005). Bullying in Schools: What Can We Glean from Self-concept Theory? Australian Association for Research in Education 2005 Conference Papers.

Penn, H. (2005). Understanding Early Childhood: Issues and Controversies. Open University Press.

Pervin, L. A. \& Cervone, D. (2013). Personality Theory and Research $\left(12^{\text {th }}\right.$ ed.). Wiley. 
Roeleveld, W. (2011). The Relationship Between Bullying and the Self-concept of Children. Social Cosmos, 2, 111-116.

Sanchez, F. J. P., \& Roda, M. D. S. (2003). Relationships Between Self-Concept and Academic Achievement in Primary Students. Electronic Journal of Research in Educational Psychology, 1(1), 95-120.

Scheerens, J., Van Der Werf, G., \& De Boer, H., (2020). Soft Skills in Education: Putting the Evidence in Perspective. Springer International Publishing AG.

Schleicher, A. (2019). PISA 2018 Insights and Implementations PISA. EOCD Publications.

Schnitzler, K., Holzberger, D., \& Seidel, T. (2020). All Better than Being Disengaged: Student Engagement Patterns and Their Relations to Academic Self-Concept and Achievement. European Journal of Psychology of Education, September.

Seaton, M., Parker, P., Marsh, H. W., Craven, R. G., \& Yeung, A. S. (2013). The Reciprocal Relations between Self-Concept, Motivation and Achievement: Juxtaposing Academic Self-Concept and Achievement Goal Orientations for Mathematics Success. Educational Psychology: An International Journal of Experimental Educational Psychology, 34(1), 49-72.

Shavelson, R. J., Hubner, J. J., \& Stanton, G. C. (1976). Self-concept: Validation of Construct Interpretations. Review of Educational Research, 46(3), 407-441.

Tabernero, C., \& Wood, R. E. (2009). Interaction between self-efficacy and initial performance in predicting the complexity of task chosen. Psychological Reports, 105(3, Pt2), 1167-1180.

Trinite, B. (2020). The Comprehension of the Concepts of Noise and Silence in Primary School Children. Society Integration Education Proceedings of the International Scientific Conference, 3, 618-627.

Tosto, M. G., Asbury, K., Mazzocco, M. M. M., Petrill, S. A., \& Kovas, Y. (2016). From Classroom Environment to Mathematics Achievement: The Mediating Role of SelfPerceived Ability and Subject Interest. Learning and Individual Differences, 50, 260-269.

Tubele, S. \& Serova, K. (2020) The Methods and Materials for Promoting Reading Literacy Skills for 6 to 7 Year Old Children. In Daniela L. (eds.), Human, Technologies and Quality of Education, 1, 51-61.

Vaughn, M. G, Maynard, B. R., Salas-Wright, C. P., Perron, B. E. \& Abdon, A. (2013). Prevalence and Correlates of Truancy in the US: Results from a National Sample. Journal of Adolescence, 36(4), 767-776.

Vesić, D., Džinović, V., \& Mirkov, S. (2021). The Role of Absenteeism in the Prediction of Math Achievement on the Basis of Self-concept and Motivation: TIMMS 2015 in Serbia. Psihologija, 54(1), 15-31.

Whitcomb, S. A., \& Merrell, K. W. (2013). Behavioural, social, and emotional assessment of children and adolescents ( $4^{\text {th }}$ ed.). Routledge/Taylor \& Francis Group. 